\title{
The biological markers and results of treatment in male breast cancer patients. The Cracow experience.
}

\author{
B. SAS-KORCZYNSKA ${ }^{1, *}$, J. NIEMIEC ${ }^{2}$, A. HARAZIN-LECHOWSKA ${ }^{3}$, S. KORZENIOWSKI ${ }^{1}$, D. MARTYNOW ${ }^{1}$, A. ADAMCZYK ${ }^{2}$, A. SOKOLOWSKI ${ }^{4}$ \\ ${ }^{1}$ Clinic of Oncology - Department of Breast and Chest Cancer, Maria Skłodowska-Curie Memorial Institute, Centre of Oncology, Cracow, Poland; \\ ${ }^{2}$ Department of Applied Radiobiology, Maria Skłodowska-Curie Memorial Institute, Centre of Oncology, Cracow, Poland; ${ }^{3}$ Department of Tumor \\ Pathology, Maria Skłodowska-Curie Memorial Institute, Centre of Oncology, Cracow, Poland; ${ }^{4}$ Department of Statistics, Cracow University of \\ Economics, Cracow, Poland
}

${ }^{*}$ Correspondence: $z 5 k o r c z y @ c y f-k r . e d u . p l$

Received August 7, 2013 / Accepted October 9, 2013

\begin{abstract}
Male breast cancer is a rare form of carcinoma with an incidence rate of approximately $0.5-1 \%$ compared with cases of breast carcinoma as a whole. Male breast cancer reacts effectively to endocrine therapy because of a high frequency of hormone receptor expression.

The aim of the present study was the assessment of correlations between stage, grade, expression of steroid receptors, basal/mesenchymal markers and proliferation index, as well as analysis of the impact of the above-mentioned parameters on overall (OS) and disease-free survival (DFS) in the group of 32 male breast cancer patients, treated at the Centre of Oncology in Cracow.

We showed the significant positive correlation between MIB-1 LI and tumor stage, and hormone receptors (ER or PgR) immunonegativity, and expression of EGFR, vimentin $(\mathrm{p}<0.05)$ and $\mathrm{P}$-cadherin (the last at statistical border). The presence of any of basal or masenchymal markers correlated with a more advanced tumor stage. Moreover tumors without vimentin expression were characterised by lower MIB-1 LI and were more frequently EGFR immunonegative.

We found that hormone receptor negativity, vimentin immunopositivity and high MIB-1 LI are significant independent indicators of poor OS and DFS for male breast cancer patients $(\mathrm{p}<0.05)$.
\end{abstract}

Key words: male breast cancer, basal markers, mesenchymal markers, nodal status, hormonal receptors

Male breast cancer is a rare form of carcinoma with an incidence rate of approximately $0.5-1 \%$ compared with cases of breast carcinoma as a whole $[1,2,3,4]$. Its peak incidence is noted in the seventh decade of life $[5,6,7]$. The most significant risk factors are an increased concentration of estrogen and obesity, that are a result of estrogen overproduction, impaired metabolism, and disturbances in the concentration of estrogen and androgen (i.e. in Klinefelter's syndrome) as well as the use of estrogenes in prostate cancer treatment $[6,8,9$, $10,11]$. Other factors include alcoholism, liver cirrhosis, the presence of hereditary BRCA1 and BRCA2 gene mutations and exposure to ionizing radiation, the electromagnetic field and increased temperature $[6,8,9,12,13,14,15,16,17]$.

According to Anderson et al., male breast cancer is characterised by similar biological factors to those present in the female variant of the cancer [18]. However, these tumors are diagnosed in more advanced stages of the disease, are characterised by higher degree of differentiation (more frequently G1, G2 grade) and a lower mitotic index in comparison to female breast cancer $[5,19]$. There are also differences in the frequency of the expression of hormone receptors and growth factor receptors $[19,20]$. Besides, the prognosis for male breast cancer is worse $[5,18,20,21]$. A study by Baojiang et al. of 5 -year survival rates of patients suffering from male breast carcinoma and female breast carcinoma produced the following results: $61.2 \%$ and $68.7 \%$ (DFS), and $75 . \%$ and $82.9 \%$ (OS), respectively [20].

Male breast cancer has a higher (over 90\%) hormone receptor expression and, as a consequence, reacts more effectively to endocrine therapy $[6,16,17,19,22,23,24,25,26,27]$.

The treatment of male breast carcinoma is based on standard methods, more specifically surgical procedures $[6,21,25$, 
Table 1. The clinical, pathological and treatment characteristic of 32 male patients with breast cancer.

\begin{tabular}{|c|c|c|c|}
\hline \multicolumn{2}{|l|}{ Clinical feature } & $\begin{array}{c}\text { No of } \\
\text { patients }\end{array}$ & $\%$ \\
\hline \multicolumn{2}{|l|}{ positive family history } & 2 & 6,3 \\
\hline \multicolumn{4}{|l|}{ stage of disease } \\
\hline & $\mathrm{T} 1$ & 4 & 12.5 \\
\hline & $\mathrm{T} 2$ & 4 & 12.5 \\
\hline & $\mathrm{T} 3$ & 1 & 3.1 \\
\hline & $\mathrm{T} 4$ & 12 & 37.5 \\
\hline & $\mathrm{Tx}$ & 11 & 34.4 \\
\hline & No & 8 & 25.0 \\
\hline & N1 & 9 & 28.1 \\
\hline & $\mathrm{N} 2$ & 3 & 9.4 \\
\hline & N3 & 1 & 3.1 \\
\hline & $\mathrm{Nx}$ & 11 & 34.4 \\
\hline $\begin{array}{l}\text { pathological stage of } \\
\text { nodes }\end{array}$ & $\mathrm{pN}+$ & 17 & 53.1 \\
\hline \multicolumn{4}{|l|}{ tumour grade } \\
\hline & G1 & 8 & 25.0 \\
\hline & G2 & 17 & 53.1 \\
\hline & G3 & 5 & 15.6 \\
\hline & $\mathrm{Gx}$ & 2 & 6.3 \\
\hline \multirow[t]{2}{*}{ surgery } & mastectomy & 31 & 96.8 \\
\hline & breast-conserving surgery & 1 & 3.2 \\
\hline \multirow[t]{3}{*}{ adjuvant therapies } & radiotherapy & 12 & 37.5 \\
\hline & chemotherapy & 10 & 31.3 \\
\hline & endocrine therapy & 18 & 56.3 \\
\hline \multirow{5}{*}{$\begin{array}{l}\text { localization of distant } \\
\text { metastases }\end{array}$} & lungs & 6 & 54.5 \\
\hline & bones & 5 & 45.5 \\
\hline & skin & 2 & 18.2 \\
\hline & brain & 1 & 9.1 \\
\hline & lymph nodes (distant) & 1 & 9.1 \\
\hline
\end{tabular}

26]. Breast amputations are more frequent in male patients than in female $[6,15,17,26]$. According to Nilsson et al., mastectomy is performed in $92 \%$ of male patients and $44 \%$ of female patients [28]. The adjuvant treatment employed in such cases (radiotherapy, chemotherapy, hormone therapy) depends on the presence of prognostic and predictive features, which are indications for this type of treatment $[5,6,12,15$, $16,23,25,26,28,29,30,31]$.

The aim of the present study was to: (i) describe the clinical and biological characteristics of breast cancers of male patients treated at the Centre of Oncology in Cracow, (ii) assess correlations between stage, grade, expression of steroid receptors, basal/mesenchymal markers and proliferation index, (iii) and analyse impact of the above-mentioned parameters on overall and disease-free survival.

\section{Patients and methods}

Patients. Between 1950 and 2010, 81 male patients with breast cancer were treated at the Centre of Oncology in Cracow. These cases represented $0.5 \%$ of all (17.320) patients treated for breast cancer in this period. The biological markers were tested in 32 cases only and this group is the subject of the following publication. The size of the group was determined by the fact that the assessment of biological parameters were carried out on archival formalin-fixed, paraffin-embedded sections, which in some cases were not adequate for immunohistochemistry (small amount of tissue in paraffin block, poor quality of material). The patients (with marker assessment) were treated between 1976 and 2010 and represented $0.2 \%$ of all the patents suffering from breast cancer during this period.

The consent to perform the above-mentioned tests was given by the Bioethic Committee of the Regional Medical Chamber in Cracow.

The age of the 32 patients ranged from 34 up to 84 years and the mean value was equal to $62.72 \pm 12.49$ on average (median: 63 years). A positive family history was noted in 2 patients (6.3\%). In table 1 the clinical and pathological characteristics and treatment methods of the 32 analysed patients are presented. The majority of the patients (40\%) were diagnosed with stage T3-T4 cancer. In 25\% of the patients no clinical features of regional lymph node metastases were noted, while in 17 patients (53.1\%) axillary lymph node metastases were confirmed in pathological examination.

All patients received surgical treatment. A total of 31 patients (96.8\%) underwent a mastectomy, whereas 1 patient (3.2\%) underwent a tumorectomy with axillary lymphadenectomy. After the surgery, 26 patients (81.2\%) received adjuvant therapy: radiotherapy, chemotherapy and endocrine therapy.

A total of 12 patients (37.5\%) received radiotherapy, whereas 8 of the patients underwent additional chemotherapy and/or endocrine therapy. Chemotherapy was administered to 10 patients, whereas 18 patents $(56.3 \%)$ were treated with endocrine therapy combined with tamoxifen. Adjuvant therapy was administered as the only treatment in 9 patients, whereas in the remaining patients adjuvant therapy was applied simultaneously with radiotherapy (3 patients) and/or chemotherapy (6 patients).

Pathological material. Archival tumor specimens were obtained from the Department of Tumor Pathology and were reviewed by pathologist to confirm histological diagnosis and tumor grade (according to Elston-Ellis modified version of the Bloom-Richardson scale).

Immunohistochemistry. Four $\mu \mathrm{m}$ sections, prepared from tissues fixed in 10\% neutral buffered formalin and embedded in paraffin, were mounted on SuperFrost ${ }^{\circledR}$ Plus slides (MenzelGläser, Braunschweig, Germany), deparaffinised and hydrated through a series of xylenes and alcohols.

Following antigen retrieval (techniques summarized in table 2), slides were incubated in $3 \% \mathrm{H}_{2} \mathrm{O}_{2}$ diluted in methanol for $30 \mathrm{~min}$. to block the activity of endogenous peroxidases. Twenty min. incubation with $2.5 \%$ horse normal serum was applied to block non-specific binding of antibodies. Next, slides were incubated with primary antibodies: for P-cadherin - $1 \mathrm{~h}$ incubation at $37^{\circ} \mathrm{C}$, for other antibodies - overnight 
Table 2. Immunohistochemical procedures used for visualization of markers.

\begin{tabular}{|c|c|c|c|c|c|}
\hline $\begin{array}{l}\text { Marker } \\
\text { /antibody }\end{array}$ & Clone & Dilution & Manufacturer & Antigen retrieval technique & $\begin{array}{c}\text { No of immunopositive / no of } \\
\text { assessed cases (\%) }\end{array}$ \\
\hline ER & $6 \mathrm{~F} 11$ & $1 / 100$ & \multirow{2}{*}{ Leica Biosystems ${ }^{1}$} & \multirow{8}{*}{$\begin{array}{c}\text { TRS, } \mathrm{pH}=6.1 \mathrm{DAKO}^{2}, 50 \\
\min ., 96^{\circ} \mathrm{C}\end{array}$} & \multirow{2}{*}{$25 / 27(78.1)$} \\
\hline PgR & $\mathrm{PGR} / 2$ & $1 / 200$ & & & \\
\hline HER2 & polyclonal & $1: 250$ & $\mathrm{DAKO}^{2}$ & & $1 / 25(3.1)$ \\
\hline $\mathrm{Ki}-67$ & MIB-1 & $1: 75$ & $\mathrm{DAKO}^{2}$ & & $24 / 24(100.0)$ \\
\hline Cytokeratin 5/6 & D5/16 B4 & $1: 50$ & $\mathrm{DAKO}^{2}$ & & \multirow{2}{*}{$4 / 29(12.5)$} \\
\hline Cytokeratin 5 & XM26 & $1: 80$ & Thermo $^{3}$ & & \\
\hline P-cadherin & 56 & $1: 200$ & $\mathrm{BD}^{4}$ & & $11 / 23(34.4)$ \\
\hline SMA & asm-1 & $1: 50$ & Leica Biosystems $^{1}$ & & $1 / 25(3.1)$ \\
\hline Vimentin & V9 & $1: 200$ & BioGenex $^{5}$ & Not applied & $2 / 28(6.3)$ \\
\hline EGFR & H11 & $1: 200$ & $\mathrm{DAKO}^{2}$ & $\begin{array}{l}\text { Proteinase } \mathrm{K} \text {, } \\
10 \min ., 37^{\circ} \mathrm{C}\end{array}$ & $3 / 28(9.4)$ \\
\hline
\end{tabular}

${ }^{1}$ Leica Biosystems Newcastle Ltd, Newcastle, UK

${ }^{2}$ DakoCytomation Denmark A/S, Glostrup, Denmark

${ }^{3}$ Thermo, Fisher Scientific, Fremont, CA, USA

${ }^{4}$ BD Biosciences Pharmingen, BD Transduction Laboratories ${ }^{\mathrm{Ts}}$, Franklin Lakes, NJ, USA

${ }^{5}$ BioGenex Laboratories Inc., San Ramin, USA

incubation at $4^{\circ} \mathrm{C}$ (clones, dilutions and manufacturers are provided in table 2). Proteins labeled with primary antibodies were visualized with BrightVision detection system (Immunologic, Duiven, The Netherlands) and 3,3'-diaminobenzidine (DAB) (Vector Laboratories, Inc., Burlingame, USA). Hematoxylin was used for nuclear counterstaining. The details of the immunohistochemical (IHC) stainings, together with the number of stained cases and number of slides with positive staining, are shown in Table 2. Staining pattern for ER, Ki-67, CK5/6, P-cadherin, SMA, vimentin and EGFR are presented in figure 1 ( $a, b, c, d, e, f, g, h$, i respectively).

IHC evaluation. IHC stainings were evaluated in the invasive component of the tumors, only. ERa (figure $1 \mathrm{a}) / \mathrm{PgR}$, CK5/6 / CK5 (figure 1c), SMA (figure 1f), vimentin (figure 1h), and EGFR expression (figure 1i) was considered positive if $>1 \%$ of tumor cells showed immunopositivity (nuclear for $\mathrm{ER} / \mathrm{PgR}$ (figure 1a), and cytoplasmic/membranous for other markers (figure $1 \mathrm{c}, \mathrm{d}, \mathrm{f}, \mathrm{h}, \mathrm{i}$ ). According to ASCO recommendation only tumors with complete intensive $(3+)$ membranous HER2 staining of $>30 \%$ of cells were considered positive [32]. P-cadherin immunopositivity was defined as complete strong membranous staining observed in $>10 \%$ of cells or strong cytoplasmic staining in $>50 \%$ of cells (figure 1d). In case of SMA and vimentin immunopositivity of stromal cells (figure $1 \mathrm{e}, \mathrm{g}$ star) or of myoepithelial cells (figure 1e arrow) was not taken into account.

MIB-1 labelling index (MIB-1 LI) was calculated as the percentage of Ki-67 immunopositive cells (figure 1b). Between 500 and 1000 cells (at $\times 400$ magnification) were counted in 5 - 10 fields for each slide.

Statistical methods. The Mann-Whitney (for continuous variables) and Kruskal-Wallis, ANOVA and $\mathrm{Chi}^{2}$ (for categorised variables) tests were employed to determine the relationship between the results of the biological analysed tests.
The probability of overall survival (OS) and disease-free survival (DFS) was calculated using the Kaplan-Meier method. The log rank test was applied to assess the influence of different factors on the results.

A Cox model multivariate analysis was also carried out. The significance level for all the tests was set at $\alpha=0.05$.

\section{Results}

Frequency and pattern of markers expression. In table 2 the frequency of markers expression was presented. The lack of results for some markers is the effect of a small amount of tissue in paraffin blocks or small fragments of tumor tissue that hindered obtaining reliable data.

ER expression was noted in 22 carcinomas (68.8\%), PgR in $20(62.5 \%)$, while steroid receptor immunopositivity (ER and/or PgR) was present in 25 tumors (78.1\%).

The proliferation index (MIB-1 LI) ranged from $11.1 \%$ to $71.1 \%$ (average $35.3 \% \pm 15.37$, median: $31.6 \%$ ). In $53.1 \%$ the MIB-1 LI was less than or equal to the cut-off value, which was $35 \%$. The above-mentioned cut-off value was established at mean value.

Correlations between studied markers and clinicopathological parameters. The relationships between the results of the immunohistochemical analysis are presented in table 3.

Significantly higher MIB-1LI was noted for more advanced tumor stage, hormone receptors (ER or PgR) immunonegativity, and expression of EGFR, vimentin $(\mathrm{p}<0.05)$ and $\mathrm{P}$-cadherin (the last at statistical border). On the other hand, the presence of any of basal or masenchymal markers correlated with a more advanced tumor stage. Moreover, tumors with lack of vimentin expression were characterised by lower MIB-1LI and more frequently EGFR immunonegativily. 

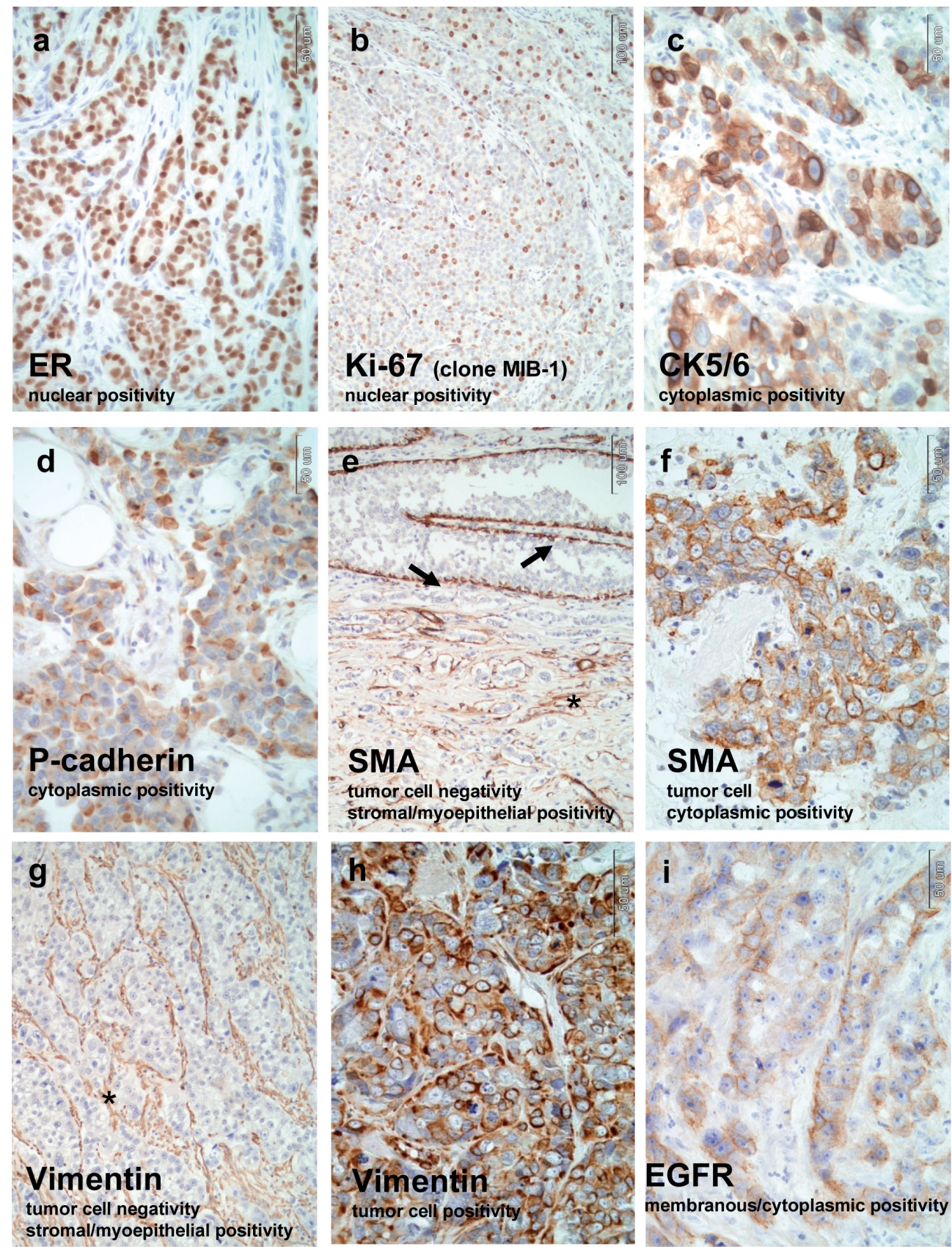

Figure 1. Results of immunohistochemical analysis of male breast cancer. Estrogen receptor immunopositivity in almost $100 \%$ of tumor cells (a), expression of Ki-67 (visualized using clone MIB-1) (b), cytoplasmic localization of CK5/6 (c) and P-cadherin (d), SMA expression in myoepithelial cells (e, arrow), stromal cells (e, star), and tumor cells (f), stromal vimentin immunopositivity (g, star), and positive reaction in tumor cells (h), weak membranous EGFR expression (i). Microphotographs a, c, d, f, h, i were taken at 40×, while b, e, g at 20× objective magnification.

Survival analysis. In the studied group of 32 male patients, the follow-up period was between 1 and 302 months (average 73 months, median: 46 months). In this period 4 patients (12.5\%) suffered from the onset of local recurrences. These recurrences occurred between 7 and 70 months (average: 28.3 months) following the treatment. In 11 patients (34.4\%) the cancer spread within a period of 1 and 251 months was observed. Table 1 presents the locations of distant metastases. The most common locations for metastases were the lungs and bones.

A second cancer was noted in 3 patients (9.4\%) (non-small cell lung cancer in 2 patients, prostate cancer in 1 patient) 
Table 3. The relationships between the results of the immunohistochemical analysis.

\begin{tabular}{|c|c|c|c|c|c|c|c|c|}
\hline \multirow{3}{*}{ Parameters } & \multicolumn{6}{|c|}{ Expression } & \multicolumn{2}{|c|}{ MIB-1LI } \\
\hline & \multicolumn{3}{|c|}{ P-cadherin } & \multicolumn{3}{|c|}{ vimentin } & \multirow{2}{*}{ mean value \pm SD } & \multirow{2}{*}{$\mathbf{p}$} \\
\hline & positive & & $\mathbf{p}$ & positive & & $\mathbf{p}$ & & \\
\hline \multicolumn{9}{|l|}{ tumour grade: } \\
\hline G1 & $1 / 8$ & $12.5 \%$ & & $0 / 8$ & - & & $30.7 \pm 7.5$ & \\
\hline $\mathrm{G} 2$ & $4 / 17$ & $23.5 \%$ & 0.0081 & $0 / 17$ & - & 0.0251 & $29.5 \pm 8.3$ & 0,0036 \\
\hline G3 & $5 / 5$ & $100.0 \%$ & & $2 / 5$ & $40.0 \%$ & & $59.4 \pm 10.7$ & \\
\hline MIB-1LI & & & 0.1645 & & & & & \\
\hline$\leq 35 \%$ & $6 / 15$ & $40.0 \%$ & & $0 / 15$ & - & 0.0224 & - & - \\
\hline$>35 \%$ & $5 / 7$ & $71.4 \%$ & & $2 / 7$ & $28.6 \%$ & & & \\
\hline hormonal receptors (ER/PgR) & & & 0.0755 & & & 0.0825 & & 0.0290 \\
\hline positive & $9 / 25$ & $36.0 \%$ & & $1 / 25$ & $4.0 \%$ & & $32.6 \pm 13.0$ & \\
\hline negative & $2 / 2$ & $100.0 \%$ & & $1 / 2$ & $50.0 \%$ & & $64.0 \pm 10.0$ & \\
\hline \multicolumn{9}{|l|}{ EGFR } \\
\hline positive & $2 / 3$ & $66.7 \%$ & 0.0654 & $1 / 3$ & $33.3 \%$ & 0.0309 & $55.9 \pm 15.7$ & 0.0181 \\
\hline negative & $8 / 25$ & $32.0 \%$ & & $0 / 25$ & - & & $30.5 \pm 10.7$ & \\
\hline \multicolumn{9}{|l|}{ vimentin } \\
\hline positive & $2 / 2$ & $100.0 \%$ & 0.0847 & - & - & - & $62.2 \pm 7.4$ & 0.0474 \\
\hline negative & $9 / 20$ & $45.0 \%$ & & & & & $33.3 \pm 13.6$ & \\
\hline \multicolumn{9}{|l|}{ P-cadherin } \\
\hline positive & - & - & - & $2 / 11$ & $1.2 \%$ & 0.0847 & $43.3 \pm 17.1$ & 0.0652 \\
\hline negative & & & & $0 / 11$ & 0 & & $27.0 \pm 10.2$ & \\
\hline
\end{tabular}

between 12 and 251 months after they had received treatment for breast carcinoma.

Twenty patients died in the follow-up period. Ten of them died from breast cancer (through the recurrence and/or spread of the cancer), two patients died as a result of a second cancer, whereas 8 patients died from non-oncological diseases.

The estimated 5-year survival rates were $57.3 \%$ (OS), and 63.1\% (DFS) (figure 2a, e respectively).

None of therapeutic features (methods of adjuvant treatment: radiotherapy, chemotherapy and endocrine therapy) had significant influence on both overall and disease-free survival rates. The 5-year OS and DFS according to presence or absence method of treatment were as following: $53.5 \%$ vs $59.2 \%, \mathrm{p}=0.8931$ and $42.3 \%$ vs $74.1 \%, \mathrm{p}=0.1149$ (adjuvant radiotherapy), $51.4 \%$ vs $57.8 \%, \mathrm{p}=0.5160$ and $60.0 \%$ vs $66.5 \%, \mathrm{p}=0.6811$ (adjuvant chemotherapy), $58.0 \%$ vs $48.2 \%, \mathrm{p}=0.7117$ and $53.1 \%$ vs $78.6 \%, \mathrm{p}=0.8150$ (endocrine therapy).

It was shown that patient's OS strongly depends on the following factors: (i) tumor grade (5-year survival rates: G1 - 62.5\%, G2 - 66.5\%, G3 - 20\%, p=0.0186) (Figure 2b), (ii) the hormone receptor status (5-year survival results: ER/PgR negativity $-22.2 \%$, and positivity $-62 \%, \mathrm{p}=0.0123$ ) (Figure $2 \mathrm{c}$ ) and (iii) vimentin (5-year survival for vimentin immunonegativity $-60 \%$, and immunopositivity $-0 \%$, $\mathrm{p}=0.0118$ ) (Figure 2d). Furthermore, the disease-free survival rates depend on: (i) status of lymph nodes (5-year survival rate results: $\mathrm{pN} 0$ in $80 \%, \mathrm{pN}+$ in $47.5 \%, \mathrm{p}=0.0329$ ) (Figure $2 \mathrm{f}$ ), (ii) hormone receptor expression (5-year survival results: receptor immunonegativity $-22.2 \%$, receptor immunoposi- tivity $-68.9 \%, \mathrm{p}=0.0053$ ) (figure $2 \mathrm{~g}$ ) and (iii) MIB-1LI (5-year survival results: MIB-1IL $\leq 35 \%$ in $74.3 \%$, MIB- 1 IL $<35 \%$ in $35.7 \%, \mathrm{p}=0.0543$ ) (Figure $2 \mathrm{~h}$ ).

The final results of the multivariate analysis were presented in table 4 . We found that

hormone receptor negativity is a significant indicator of poor overall and disease-free survival (table 4). In addition, vimentin immunopositivity and high MIB-1LI are significant independent prognostic factors of poor overall and diseasefree survival respectively (table 4).

\section{Discussion}

Male breast cancer is a rare form of carcinoma. In the literature the size of the analysed groups ranges from 31 to 118 patients, studied over a periods from 14 to 47 years [15, $16,20,21,27,28,29,31,33]$. The number of male patients treated for breast carcinoma at the Institute of Oncology in

Table 4. The results of Cox proportional hazards for 32 male breast cancer patients.

\begin{tabular}{lccc}
\hline Variable and value & RR & $\mathbf{9 5 \%}$ CI & p \\
\hline Overall survival & & & \\
\hline ER/PgR immunonegativity & 4.12 & $0.090-0.659$ & 0.0054 \\
vimentin immunopositivity & 21.8 & $2.602-182.699$ & 0.0045 \\
\hline Disease-free survival & & & \\
\hline MIB-1LI $>35 \%$ & 5.2 & $1.335-20.252$ & 0.0175 \\
ER/PgR immunonegativity & 6.94 & $0.041-0.498$ & 0.0022 \\
\hline
\end{tabular}




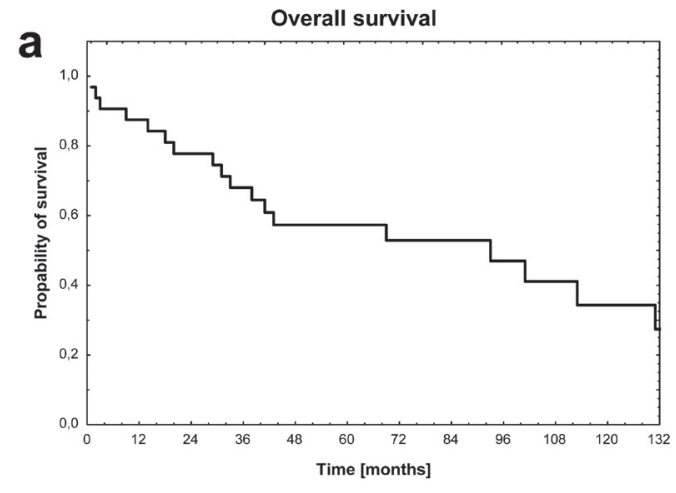

Overall survival according to:
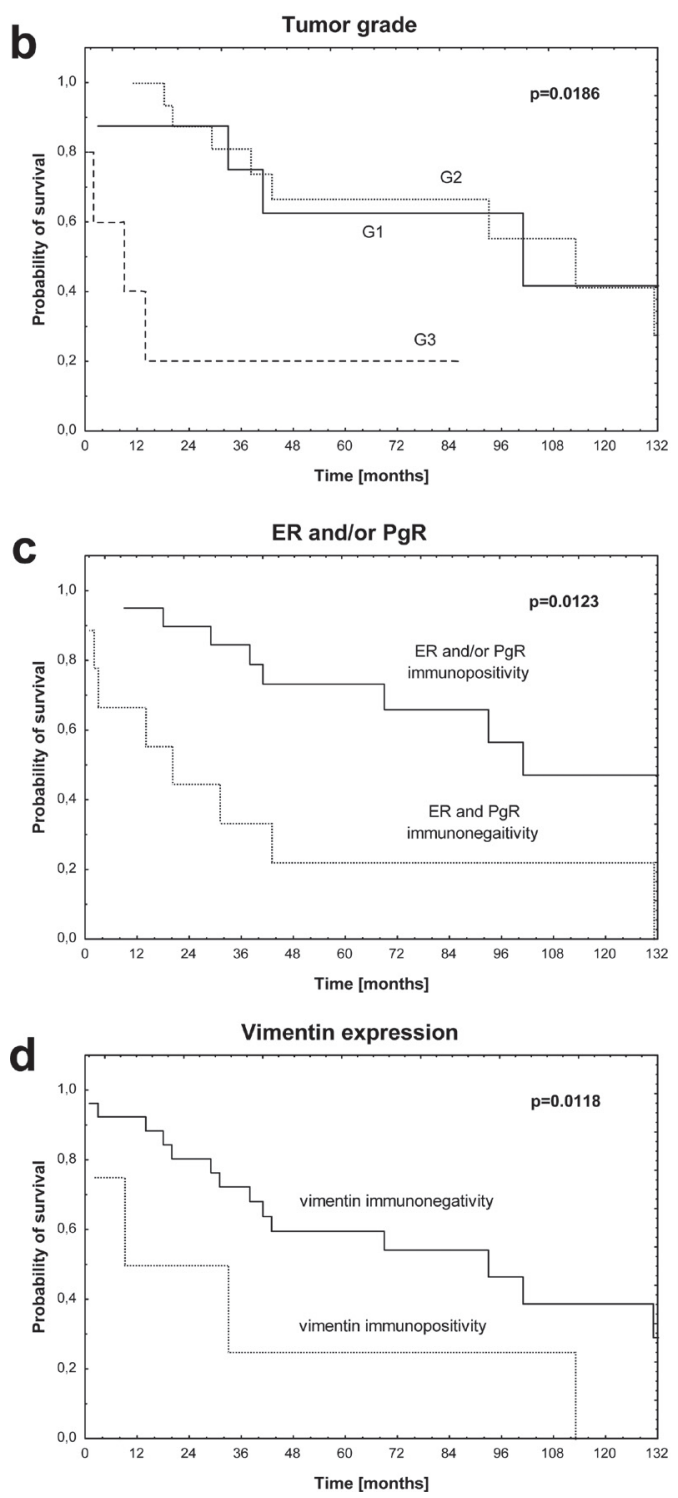

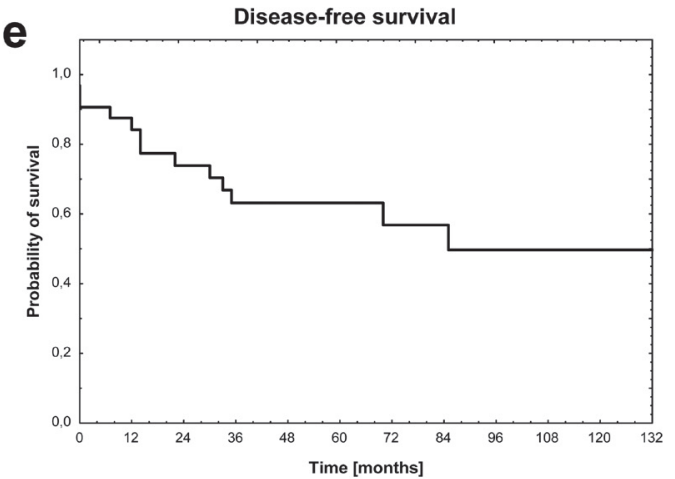

Disease-freel survival according to:
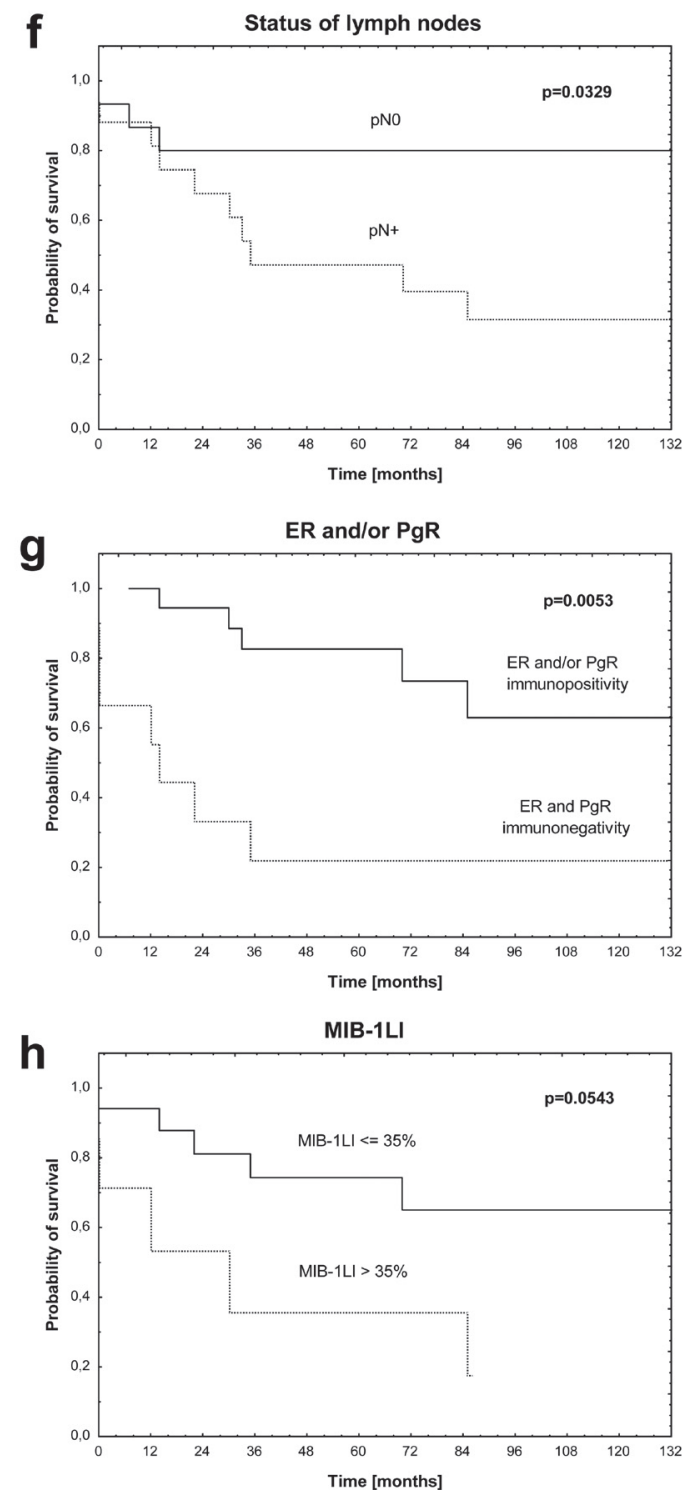

Figure 2. Overall survival in male patients with breast cancer: whole group (a), and according to: tumor grade (b), ER and/or PgR status (c) and vimentin expression (d).

Disease-free survival in male patients with breast cancer: whole group (e), and according to: status of lymph nodes (f), ER and/or PgR status (g) and MIB-1 LI (h). 
Cracow is similar. Between 1960 and 2010, a total 81 patients were treated, while biological markers were carried out on the 32 patients treated between 1976 and 2010 year. The size of this group was limited as the biological markers assessments were carried out on archival paraffin sections, which in some cases were unreliable.

In our study the 5-year survival rates was $57.3 \%(\mathrm{OS})$ and $63.1 \%$ (DFS). These rates are comparable to the results presented in the literature, which are as follows: $41-75 \%$ for 5 -year (OS) and 60-73\% (DFS) [20, 21, 25, 28, 31, 34].

It was indicated that the most important prognostic factor for male breast cancer patients is the presence of metastases in the lymph nodes $[21,27,31,34]$. Our observations are similar. We observed lymph nodes involvement in 17 out of the 32 patients (53.1\%). Other authors reported lymph nodes metastases in $46-50 \%$ of the male patients with breast cancer $[25,27,34]$. In our study the presence of lymph node metastases significantly decreases cancer-free survival rates. The 5 -year OS rate depends on the status of the lymph nodes. For pN0 is $80.0 \%$ and for $\mathrm{pN}+$ is $47 \%$.

The other, frequently reported, significant factor determining a patient's prognosis was hormone receptor status. We found the correlation between the hormone receptor negativity and a poor prognosis (relative risk is 4.12 and 6.94 for OS and DFS, respectively). It should be pointed out that in our study 20 out of the 32 patients $(62.9 \%)$ showed expression of ER and/or PgR. Due to this fact, male patients suffering from breast cancer responded better to hormonal therapy. These statement is in agreement with other authors indicating a higher survival rate (over 90\%) for patients with such tumors $[6,17,19,23,25,26,27]$.

We observed significantly higher MIB-1LI for ER/PgR negative carcinomas (64\%) than for positive ones (32.6\%) $(\mathrm{p}=0.0290)$. The cut-off point for MIB-1LI found in our study for male breast carcinomas is relatively high (35\%) but comparable to that reported by other authors $(13.25 \%-30 \%)$ $[35,36,37,38,39]$. This might be the result of application of a very sensitive visualization system (utilizing polymerised peroxidases as DAB substrate) and inclusion of patients with more advanced clinical stage.

Relation between MIB-1LI or steroid receptor status and patients survival in male breast cancer is not surprising as these markers are known prognostic indicators $[35,36,37$, $38,39]$.

The multivariate analysis indicated that the high MIB-1LI was the negative prognostic factor which determined shorter disease-free survival rates. The relative risk related to the above-mentioned factor was 6.94. Moreover, it was shown that $\mathrm{P}$-cadherin and vimentin expression was observed more frequently in high grade tumors. This result is in agreement with other authors results who noted relation between expression of basal and/or mesenchymal markers and basal breast cancer immunophenotype or high grade $[39,40]$. It was also observed that the vimentin expression was independing prognostic factor for OS related to relative risk of 21.8.
Poor survival found for patients with carcinomas presenting vimentin expression (mesenchymal marker) might be explained by higher aggressiveness of tumors showing features of epithelial-mesenchymal transition (process related to increased invasiveness and metastatic potential) [41].

According to the literature, the hormone receptor negativity as well as vimentin expression was related to increased tumor proliferative activity, while vimentin immunopositivity was the main factors leading to a negative prognosis for patients with breast cancer $[40,42,43]$. Moreover vimentin, CK5/6 and EGFR expression is noted more frequently in cancers with hormone receptor immunonegativity[44].

Prognostic significance of the biological markers found in our series of male breast cancer need to be confirmed on a larger group of patients.

\section{Conclusions}

1. In male breast cancer the steroid receptor immunopositivity (ER and/or PgR) was present in $25(78.1 \%)$ cases.

2. The estimated 5 -year OS rate was $57.3 \%$. For the same time point DFS rate was $63.1 \%$

3. The hormone receptor negativity, vimentin immunopositivity and high MIB-1 LI are significant independent prognostic factor of poor male breast cancer patients survival.

\section{References}

[1] JEMAL A, SIEGEL R, WARD E, HAO Y, XU J, et al. Cancer statistics, 2009. CA Cancer J Clin 2009; 59: 225-249. http:// dx.doi.org/10.3322/caac.20006

[2] FENTIMAN IS, FOURQUET A, HORTOBAGYI GN. Male breast cancer. Lancet 2006; 367: 595-604. http://dx.doi. org/10.1016/S0140-6736(06)68226-3

[3] WHITE J, KEARINS O, DODWELL D, HORGAN K, HANBY $\mathrm{AM}$, et al. Male breast carcinoma: increased awareness needed. Breast Cancer Res 2011; 13: 219-225. http://dx.doi. org/10.1186/bcr2930

[4] SPEIRS V, SHAABAN AM. The rising incidence of male breast cancer. Breast Cancer Res Treat 2009; 115: 429-430. http://dx.doi.org/10.1007/s10549-008-0053-y

[5] GNERLICH JL, DESHPANDE AD, JEFFE DB, SEELAM S, KIMBUENDE E, et al. Poorer survival outcomes for male breast cancer compared with female breast cancer may be attributable to in-stage migration. Ann Surg Oncol 2011; 18: 1837-1844. http://dx.doi.org/10.1245/s10434-010-1468-3

[6] GMEZ-RAPOSO C, TEVAR FZ, MOYANO MS, GOMEZ ML, CESADO E. Male breast cancer. Cancer Treat Rev 2010; 36: 451-457. http://dx.doi.org/10.1016/j.ctrv.2010.02.002

[7] ANDERSON WF, ALTHUIS MD, BRINTON LA, DEVESA SS. Is male breast cancer similar or different than female breast cancer? Breast Cancer Res Treat 2004; 83: 77-86. http://dx.doi. org/10.1023/B:BREA.0000010701.08825.2d

[8] JOHANSEN TABER KA, MORISY LR, OSBAHR III AJ, DICKINSON BD. Male breast cancer: Risk factors, diagno- 
sis, and management (Reviev). Oncology Reports 2010; 24: 1115-1120. http://dx.doi.org/10.3892/or 00000962

[9] JOHNSON KC, PAN S, MAO Y, Canadian Cancer Registers Epidemiology Research Group. Risk factors for male breast cancer in Canada, 1994-1998. Eur J Cancer Prev 2002; 11: 253-263. http://dx.doi.org/10.1097/00008469-200206000$0 \underline{0009}$

[10] KARLSSO CT, MALMER B, WIKLUND F, GRONBERG H. Breast cancer as a second primary in patients with prostate cancer- estrogen treatment or association with family history o cancer? J Urol 2006; 176: 538-543. http://dx.doi.org/10.1016/ j.juro.2006.03.036

[11] SORENSEN HT, FRIIS S, OLSEN JH, THULSTRUP AM, MELLEMKJAER L, et al. Risk of breast cancer in men with liver cirrhosis. Am J Gastroenterol 1998; 93: 231-233.

[12] OTTINI L, PALLI D, RIZZO S, FEDERICO M, BAZAN V, et al. Male breast cancer. Crit Rev Oncol Hematol 2010; 73: 141-155. http://dx.doi.org/10.1016/j.critrevonc.2009.04.003

[13] GUENEL P, CYR D, SABROE S, LYNGE E, MERLETTI F, et al. Alcohol drinking may increase risk of breast cancer in men: A European population-based case-control study. Cancer Causes Control 2004; 15: 571-580. http://dx.doi. org/10.1023/B:CACO.0000036154.18162.43

[14] DEB S, JENE N, KCONFAB INVESTIGATORS, FOX SB. Genotypic and phenotypic analysis of familial male breast cancer shows under representation of the HER2 and basal subtypes in BRCA-associated carcinomas. BMC Cancer 2012; 12: 510-522. http://dx.doi.org/10.1186/1471-2407$\underline{12-510}$

[15] CUTUli B, DILHUYDY JM, DE LAFONTAN B, BERLIE J, LACROZE M, et al. Ductal carcinoma in situ of the male breast. Analysis of 31 cases. Eur J Cancer 1997; 33: 35-38. http://dx.doi.org/10.1016/S0959-8049(96)00436-4

[16] ZURRIDA S, NOLE F, BONNANNI B, MASTROPASQUA MG, ARNONE P, et al. Male breast cancer. Future Oncol 2010; 6: 985-991. http://dx.doi.org/10.2217/fon.10.55

[17] RUDDY KJ, WINER EP. Male breast cancer: risk factors, biology diagnosis, treatment, and survivorship. Ann Oncol 2013; 1-9 (doi: 10.1093/annonc/mdt025). http://dx.doi. org/10.1093/annonc/mdt025

[18] ANDERSON WF, JATOI I, TSE J, ROSENBERG PS. Male breast cancer: A population-based comparison with female breast cancer. J Cin Oncol 2010; 28: 232-239. http://dx.doi. org/10.1200/JCO.2009.23.8162

[19.] VERMEULEN JF, KORNEGOOR R, VAN DER WALL E, VAN DER GROEP P, VAN DIEST P. Differential expression of growth factor receptors and membrane-bound tumor markers for imaging in male and female breast cancer. PLOS ONE 2013; 8: e53353. http://dx.doi.org/10.1371/journal. pone. 0053353

[20] BAOJIANG L, TINGTING L, GANG L, LI Z. Male breast cancer: A retrospective study comparing survival with female breast cancer. Oncology Letters 2012; 4: 642-646.

[21] LIU T, TONG Z, HE L, ZHANG L. Clinopathological characteristics and survival analysis of 87 male breast cancer cases. Breast Care 2011; 6: 446-451. http://dx.doi.org/10.1159/ $\underline{000335204}$
[22] VISRAM H, KANJI F, DENT SF. Endocrine therapy for male breast cancer: rates of toxicity and adherence. Current Oncology 2010 17: 17-21.

[23] ONAMI S, OZAKI M, MORTIMER JE, PAL SK. Male breast cancer: An update in diagnosis, treatment and molecular profiling. Maturitas 2010; 65: 308-314. http://dx.doi. org/10.1016/j.maturitas.2010.01.012

[24] GIORDANO SH, BUZDAR AU, HORTOBAGYI GN. Breast cancer in men. Ann Intern Med 2002; 137: 678-687. http:// dx.doi.org/10.7326/0003-4819-137-8-200210150-00013

[25] LIUKKONEN S, SAARTO T, MAENPAA H, SJOSTROM-MATTSON J. Male breast cancer: a survey at the Helsinki University Central Hospital during 1981-2006. Acta Oncol 2010; 49: 322-327. http://dx.doi.org/10.3109/ 02841861003591723

[26] JAIYESIMI IA, BUZDAR AU, SAHIN AA, ROSS MA. Carcinoma of the male breast. Ann Intern Med 1992; 117: 771-777. http://dx.doi.org/10.7326/0003-4819-117-9-771

[27] VAYSSE C, SROUSSI J, MALLON P, FERON JG, RIVAIN $\mathrm{AL}$, et al. Prediction of axillary lymph node status in male breast carcinoma. Ann Oncol 2013; 24: 370-376. http://dx.doi. org/10.1093/annonc/mds283

[28] NILSSONC, HOLMQVIST M, BERGKVIST L, HEDENFALK I, LAMBRE M, et al. Similarities and differences in the characteristics and primary treatment of breast cancer in men and women - a population based study (Sweden). Acta Oncol 2011;

[29] VETTO J, JUN SY, PADUCH D, EPPICH H, SHIH R. Stages at presentation, prognostic factors, and outcome of breast cancer in males. Am J Surg 1999; 177: 379-383. http://dx.doi. org/10.1016/S0002-9610(99)00067-7

[30] YONEY A, KUCUK A, UNSAL M. Male breast cancer: A retrospective analysis. Cancer Radiotherapie 2009; 13: 103-107. http://dx.doi.org/10.1016/j.canrad.2008.11.011

[31] STRANZL H, MAYER R, QUEHENBERGER F, PRETTENHOFER U, WIIFURTH P, et al. Adjuvant radiotherapy in male breast cancer. Radiother Oncol 1999; 53: 29-35. http://dx.doi. org/10.1016/S0167-8140(99)00122-X

[32] WOLFF AC, HAMMOND ME, SCHWARTZ JN, HAGERTY KL, ALLRED DC, et al. American Society of Clinical Oncology/College of American Pathologists guideline recommendations for human epidermal growth factor receptor 2 testing in breast cancer. J Clin Oncol 2007; 25: 118-45. http://dx.doi.org/10.1200/JCO.2006.09.2775

[33] MADEIRA M, MATTAR A, PASSOS RJ, MORA CD, MAMEDE LH, et al. A case report of male breast cancer in a very young patient: What is changing? J Surg Oncol 2011; 1: $9-16$.

[34] ARSLAN UY, OKSUZOGGLU B, OZDEMIR N, AKSOY S, ALKIS N, et al. Outcome of non-metastatic male breast cancer: 118 patients. Med Oncol 2012; 29: 554-560. http://dx.doi. org/10.1007/s12032-011-9978-9

[35] GOLDHIRSCH A, WOOD WC, COATES AS, GELBER RD, THURLIMANN B, et al. Strategies for subtypes dealing with the diversity of breast cancer: highlights of the St. Gallen International Expert Consensus on the Primary Therapy of Early Breast Cancer 2011. Ann Oncol 2011; 22: 1736-47. http://dx.doi.org/10.1093/annonc/mdr304 
[36] CHEANG MC, CHIA SK, VODUC D, GAO D, LEUNG S, et al. Ki67 index; HER2 status; and prognosis of patients with luminal B breast cancer. J Natl Cancer Inst 2009; 101: 736-50. http://dx.doi.org/10.1093/jnci/djp082

[37] PENAULT-LLORCA F, ANDRE F, SAGAN C, LACROIXTRIKI M, DENOUX Y, et al. Ki67 expression and docetaxel efficacy in patients with estrogen receptor-positive breast cancer. J Clin Oncol 2009; 27: 2809-15. http://dx.doi.org/ 10.1200/JCO.2008.18.2808

[38] DUMONTET C, KRAJEWSKA M, TREILLEUX I, MACKEY JR, MARTIN M, et al. BCIRG 001 molecular analysis: prognostic factors in node-positive breast cancer patients receiving adjuvant chemotherapy. Clin Cancer Res 2010; 16: 3988-97. http://dx.doi.org/10.1158/1078-0432.CCR-10-0079

[39] NIEMIEC J, ADAMCZYK A, MALECKI K, AMBICKA A, RYS J. Tumor Grade and Matrix Metalloproteinase 2 Expression in Stromal Fibroblasts Help to Stratify the High-Risk Group of Patients With Early Breast Cancer Identified on the Basis of St Gallen Recommendations. Clin Breast Cancer 2013; 13: 119-28. http://dx.doi.org/10.1016/j.clbc.2012.12.005

[40] RODRIGUEZ-PINILLA SM, SARRIO D, HONRADO E, MORENO-BUENO G, HARDISSON D, et al. Vimentin and laminin expression is associated with basal-like phenotype in both sporadic and BRCA1-associated breast carcinomas. J Clin Pathol 2007; 60: 1006-1012. http://dx.doi.org/10.1136/ jcp.2006.042143

[41] SARRIO D, RODRIGUEZ-PINILLA SM, HARDISSON D, CANO A, MORENO-BUENO G, et al. Epithelial-mesenchymal transition in breast cancer relates to the basal-like phenotype. Cancer Res 2008; 68: 989-97. http://dx.doi. org/10.1158/0008-5472.CAN-07-2017

[42] GOLMOHAMMADI R, PEJHAN A. The prognostic value of the $\mathrm{P} 53$ protein and the Ki6 marker in breast cancer patients. J Pak Med Assoc 2012; 62: 871-875.

[43] UEMURA S, TAKEKOSHI S, SUZUKI Y, SAIYOH Y, TOKUDA Y, et al. Estrogen receptor-negative and human epidermal growth factor receptor 2-negative breast cancer tissue have the highest Ki-67 labeling index and EGFR expression: gene amplification does not contribute to EGFR expression. Oncol Rep 2005; 14: 337-343.

[44] LIVASY CA, KARACA G, NANDA R, TRETIAKOVA MS, OLOPADE OI, et al. Phenotypic evaluation of the basal-like subtype of invasive breast carcinoma. Modern Pathology 2006; 19: 264-271. http://dx.doi.org/10.1038/modpathol.3800528 